\title{
Factors influencing non-academic achievements of the Bangladeshi students- An online questionnaire based study
}

Md. Rabiul

Department of Statistics, University of Dhaka

Md. Hasibur Rahman

Department of Statistics, University of Dhaka

Maksuda Aktar Toma

Department of Statistics, University of Dhaka

Pranta Das ( $\sim$ pranta.du.stat@gmail.com )

Department of Statistics, University of Dhaka https://orcid.org/0000-0003-2290-2200

\section{Research Article}

Keywords: Non-academic achievements, parent's encouragement, parent's income

Posted Date: April 12th, 2021

DOI: https://doi.org/10.21203/rs.3.rs-410311/v1

License: () (1) This work is licensed under a Creative Commons Attribution 4.0 International License. Read Full License 


\section{Abstract Introduction}

Non-academic achievements are equally prioritized along with academic achievements throughout the world and similarly in Bangladesh. But there are no literature addressing which factors are influencing student's non-academic achievements. As a result, this study was conducted in order to find which factors are influencing student's academic achievements.

\section{Methods}

The data for the study was collected through an online google form. The link of the google form was shared through different social networking sites and the responses were completely voluntary. The non-academic achievement score was the response variable of the study which was calculated from the different criterion of the non-academic achievements. Residence, parent's socio-economic status and encourages or not were inspected as the potential factors influencing non-academic achievements. Regression model was built between response and explanatory variables using backward elimination technique to select which factors are influencing non-academic achievements.

\section{Results}

Among the potential factors final model suggests that only father's education level, parent's total monthly income and whether parent's encourage to extracurricular activities or not were found as responsible factors influencing student's non-academic achievements.

\section{Conclusion}

As the factors- father's educational status, parent's monthly total income- are beyond the control so what all the parents can do is to encourage their children to do extra-curricular activities as this may lead to more non-academic achievements in the life of their children. Initiative should be taken to build awareness among the parents so that they can understand the importance of non-academic achievements as well as encouraging their children to do extra-curricular activities.

\section{Introduction}

Academic achievements of a student are the achievements which are attained by the student in their short or long term educational goals such as completion of bachelor's degree, post-graduate degrees etc. (Academic achievement). Non-academic achievements are achievements other than academic achievements that involves doing extra-curricular activities, affiliation with any kind of organizations, sports academy etc. According to US Census Bureau about fifty-seven percent of the children within age 6-17 years old participate in at least one after-school extracurricular activities (US Census Bureau). So globally students are participating in different extra-curricular activities therefore resulting in non-academic achievements.

A study conducted in Bangladesh found that in a small sample of 475 students most of the students participating in extra-curricular activities (Ahmad et al., 2015). The Daily Star, one of the dailies of Bangladesh, reported the Prime Minister of Bangladesh saying "The schools should give extracurricular activities as much importance as studies" (The Daily Star). In almost every school, colleges, and universities of Bangladesh there are presence of social organizations like "Rover-scout", "BNCC", "Red-crescent" etc. enabling the students to be affiliated with different organizations. Many governmental and non-governmental institutions are holding different type of cultural competitions and sports tournament which results in encouraging the students to learn and participate in cultural and sporting activities. Therefore, the government of Bangladesh is emphasizing on extra-curricular activities along with the academic studies which implies emphasizing on non-academic achievements along with academic achievements.

Parents participating actively in children's education found to promote children's academic growth (Green et al., 2007). Across the countries Australia, Austria, Belgium, Brazil, Canada, Czech Republic, Denmark, Finland, France, Germany, Greece, Hungary, Iceland, Ireland, Italy, Korea, Latvia, Luxembourg, Mexico, Netherlands, New Zealand, Norway, Poland, Portugal, Russia, Spain, Sweden, Switzerland, United Kingdom, United States on an average 12\% and 13\% variation in the student's performance was accounted by parent's educational and parent's occupational status respectively (Marks, 2008). One study demonstrated that parental involvement has positive effect on student's academic self-efficacy (Fan \& Williams, 2009). Furthermore, the structure of the family also influences the achievement level of the students (Amato and Keith, 1991; Hetherington, Stanley-Hagan, \& Anderson, 1989). So there are vast literatures addressing which factors can influence student's academic achievements. But unfortunately there are no literature addressing which factors are associated with student's non-academic achievements. As it is seen that non-academic achievements are equally prioritized with academic achievements so it is essential to determine which factors are influencing the non-academic achievements of the students so that policies can be made regarding which factors should be addressed in order to enhance student's non-academic achievements. As a result, this study investigates which factors are influencing student's non-academic achievements.

\section{Materials And Methods}

\section{Procedure}


The target population for this was all the university students of Bangladesh regardless of gender, residence, wealth index. The age limits of the students were 18-25 years. The study used questionnaire as a data collection tool. By using the questions in the questionnaire an online Google form was made. The link of the Google form was shared via social networking sites. And the voluntary response of the participants was recorded. The responses from students not fulfilling the inclusion criteria that is responses from students from school and colleges, students not fulfilling the age limits were excluded later. So the sampling used in this study is voluntary sampling.

\section{Outcome variable}

The non-academic achievement score is the outcome variable of the study. Each respondent's non-academic achievement score was measured using criterion how many Olympiad participated (0,1-3, More than 3), how many competitions -Language competition, debate competition, dance competition such typesparticipated (0,1-3, More than 3), singing or dancing which learned (None, Singing, Dancing, Both), photography or musical instrument which learned (None, Photography, Musical instrument, Both), art or poem reciting which learned (None, Art, Poem reciting, Both), Sports academy or social organizations in which was affiliated (None, Sports academy, Social organizations, Both). The response from each criterion was given score, for first two criterion mark was given 0 , 1 , 2 for the order of options presented and for rest of the criterion mark was given $0,1,1,2$ for the order of options displayed. Then finally each respondents nonacademic score was obtained by summing over the mark obtained in each criterion.

\section{Predictor variables}

Student's residential area (Urban, Mofussil, Rural), father's education level (Primary, Secondary, Higher secondary, Graduate, Post graduate), mother's education level (Primary, Secondary, Higher secondary, Graduate, Post graduate), parent's monthly total income (Below 15000, 15000-30000, 30000-50000, Above 50000), Encourage to do extra-curricular activities (Yes, No) were selected as the potential predictors of the non-academic achievement score.

\section{Statistical Analysis}

At first all the missing responses were deleted from the data. Initially a linear regression model was fitted keeping all the predictors as the explanatory variables. Then using backward elimination techniques final model, model with all the significant predictors, was selected. The diagnostic of the model was assessed. All the p-values less than 0.05 were considered as significant. All the analysis was done by using SPSS version 25 .

\section{Results}

\section{Characteristics of the participants}

In the Sample, $60.62 \%$ of the respondents are from urban areas and $20.09 \%$ are from rural areas and rest of the respondents are from mofussil areas. Most of the respondents (40.55\%) father have completed graduation, and least $11.02 \%$ have completed their secondary education. And most of the respondent's mother about 25.98\% have completed their Secondary education. More details about the characteristics of the respondents are presented in Table 1. 
Table 1

Characteristics of the respondents

\begin{tabular}{|c|c|c|}
\hline Variables & $\mathbf{N}$ & Percentage (\%) \\
\hline Residence & 51 & 20.09 \\
\hline • Rural & 49 & 19.29 \\
\hline - Mofussil & 154 & 60.62 \\
\hline \multicolumn{3}{|l|}{ • Urban } \\
\hline Father's Education Level & 29 & 11.42 \\
\hline - Primary or less & 28 & 11.02 \\
\hline - Secondary & 35 & 13.78 \\
\hline • Higher Secondary & 103 & 40.55 \\
\hline - Graduate & 59 & 23.23 \\
\hline \multicolumn{3}{|l|}{ - Postgraduate } \\
\hline Mother's Education Level & 37 & 14.57 \\
\hline - Primary or less & 66 & 25.98 \\
\hline - Secondary & 57 & 22.44 \\
\hline • Higher Secondary & 62 & 24.41 \\
\hline - Graduate & 32 & 12.60 \\
\hline \multicolumn{3}{|l|}{ - Postgraduate } \\
\hline Parent's total monthly Income & 46 & 18.10 \\
\hline • Below 15000 & 80 & 31.50 \\
\hline$\cdot 15000-30000$ & 63 & 24.80 \\
\hline$\cdot 30000-50000$ & 65 & 25.60 \\
\hline \multicolumn{3}{|l|}{ - Above 50000} \\
\hline Encourage to do extra-curricular activities & 90 & 35.40 \\
\hline • No & 164 & 64.60 \\
\hline - Yes & & \\
\hline
\end{tabular}

\section{Factors Associated with non-academic achievements}

The regression model suggests that non-academic achievements are associated with father's education level, parents' total monthly income and their encouragement on doing extracurricular activities (Table 2). Regarding father's education level, student's whose father has higher secondary level education have non-academic achievement score on an average 2.019 less than the student's whose father has postgraduate level education. Regarding parent's total monthly income, students whose parent's total monthly income is below 15000 have non-academic achievement score on an average 1.234 less than the students whose parent's total monthly income is above 50000. Finally, students whose parents do not encourage to do extra-curricular activities have nonacademic achievement score on an average 1.292 less than the students whose parents encourage to do extra-curricular activities. 
Table 2

Factors associate with non-academic achievements.

\begin{tabular}{|c|c|c|c|}
\hline \multirow[t]{2}{*}{ Variables } & \multirow{2}{*}{$\begin{array}{l}\text { Regression } \\
\text { coefficients }\end{array}$} & \multicolumn{2}{|l|}{$95 \% \mathrm{Cl}$} \\
\hline & & Lower & Upper \\
\hline Father's Education Level & -1.080 & -2.170 & 0.009 \\
\hline - Primary or less & -0.796 & -1.893 & 0.300 \\
\hline - Secondary & $-2.019 *$ & -2.979 & -1.059 \\
\hline • Higher Secondary & -0.615 & -1.310 & 0.080 \\
\hline - Graduate & Ref. & & \\
\hline \multicolumn{4}{|l|}{ - Postgraduate } \\
\hline Parents total monthly income & $-1.234^{\star}$ & -2.227 & -.242 \\
\hline • Below 15000 & -0.468 & -1.219 & .284 \\
\hline • $15000-30000$ & 0.078 & -.684 & .839 \\
\hline$\cdot 30000-50000$ & Ref. & & \\
\hline \multicolumn{4}{|l|}{ - Above 50000} \\
\hline Encourage to do extra-curricular activities & $-1.292^{\star}$ & -1.872 & -.711 \\
\hline • No & Ref. & & \\
\hline - Yes & & & \\
\hline Note: $\mathrm{Cl}$; confidence interval, *; significant. & & & \\
\hline
\end{tabular}

\section{Discussion}

In education life everyone is concerned with the academic or institutional achievements, always searching for way to increase the academic achievements as a result forgets that there is also a term non-academic achievements. Non-academic achievements are also as necessary as the academic achievements. So this study explored the factors which are associated with the non-academic achievements of the students. The study found that father's education level, parent's total monthly income, and whether parents encourage to do extracurricular activities or not these three factors were significantly associated with the non-academic achievements of the students.

This study found that students whose father is more educated and whose parents belong to higher total monthly income group have more non-academic achievements. Several studies demonstrated the relationship between parent's socio-economic status and academic achievements of the students (Eamon, 2005; Newhouse \& Beegle, 2006). Students who have low socio-economic status have significantly less test score compared to the students belonging to high socio-economic status group (Newhouse \& Beegle, 2006). Low socio-economic status circumscribe the access to vital resources, exposure to opportunities, and creates hindrance in all aspects of life which includes academic achievements (Eamon, 2005). In authors opinion as low socio-economic status creates the above problems this could also be the reason of prevalence of less non-academic achievements in the students whose father is less educated and parents belonging to low monthly total income group in our study.

This study also found that students whose parents encourage to do extra-curricular activities have more academic achievements than the students whose parents do not encourage to do extra-curricular activities. Several studies investigated the association between parental involvement and student's academic achievements (Domina, 2005; McNeal, 2001; Muhammad et al., 2013). Parental involvement helps to enhance the academic achievements of the children (Muhammad et al., 2013). Similarly, parental involvement for example parent child discussion have significantly positive effect on child achievements(McNeal, 2001). Some study also contradicts with the association between parental involvement and students' academic achievements such as the study conducted by Domina in 2005 found that parental involvement does not independently improves children learning. Still in authors opinion as parental involvement has positive impact on students' academic achievements this could also be the reason why students whose parents encourage to do extra-curricular activities are having more non-academic achievements.

\section{Conclusion}

The study found that only father's educational status, parent's monthly total income and parental encouragement as the factors influencing student's nonacademic achievements. As the factors, father's educational status, parent's monthly total income, are beyond the control so what all the parents can do is to encourage their children to do extra-curricular activities as this may lead to more non-academic achievements in the life of their children. Initiative should be 
taken to build awareness among the parents so that they can understand the importance of non-academic achievements as well as encouraging their children to do extra-curricular activities.

\section{Limitations}

The study has some limitations these are as the study is cross sectional in nature so causation cannot be drawn from the results. Furthermore, the study is conducted using a low sample size and the sampling is not a random sampling. Besides the appropriate sample size for the was not determined at the beginning of the study.

\section{Declarations}

\section{Author's contribution}

PD and MR developed the study concept. MHR analyzed the data. MHR, MR, MAT, PD drafted the manuscript. All the authors critically reviewed and approved the final version of the manuscript.

\section{Acknowledgement}

None

\section{Ethical issues}

Consent of the respondents were taken before collecting data.

\section{Competing interests}

The authors declare that they have no competing interests

\section{Funding}

None

\section{References}

Ahmad, M., Mf, R., Ali, M., Fn, R., \& Mas, A. (2015). Effect of Extra Curricular Activity on Student 's Academic Performance. 11(2).

Amato, P. R., \& Keith, B. (1991). Parental Divorce and Adult Well-Being: A Meta-Analysis. Journal of Marriage and the Family, $53(1), 43$.

https://doi.org/10.2307/353132

Domina, T. (2005). Leveling the home advantage: Assessing the effectiveness of parental involvement in elementary school. Sociology of Education, 78(3), 233-249. https://doi.org/10.1177/003804070507800303

Eamon, M. K. (2005). Social-demographic, school, neighborhood, and parenting influences on the academic achievement of latino young adolescents. Journal of Youth and Adolescence, 34(2), 163-174. https://doi.org/10.1007/s10964-005-3214-x

Green, C. L., Walker, J. M. T., Hoover-Dempsey, K. V., \& Sandler, H. M. (2007). Parents' Motivations for Involvement in Children's Education: An Empirical Test of a Theoretical Model of Parental Involvement. Journal of Educational Psychology, 99(3), 532-544. https://doi.org/10.1037/0022-0663.99.3.532

Marks, G. N. (2008). Are Father 's or Mother's Socioeconomic Characteristics More Important Influences on Student Performance? Recent International Evidence. 293-309. https://doi.org/10.1007/s11205-007-9132-4

McNeal, R. B. (2001). Differential effects of parental involvement on cognitive and behavioral outcomes by socioeconomic status. Journal of SocioEconomics, 30(2), 171-179. https://doi.org/10.1016/S1053-5357(00)00100-1

Muhammad, H., Rafiq, W., Sohail, M. M., \& Saleem, M. (2013). Parental Involvement and Academic Achievement; A Study on Secondary School Students of Lahore, Pakistan. Parental Involvement and Academic Achievement; A Study on Secondary School Students of Lahore, Pakistan, 3(8), $209-223$.

Newhouse, D., \& Beegle, K. (2006). The Effect of School Type on Academic Achievement. Journal of Human Resources, XL/(3), $529-557$. https://doi.org/10.3368/jhr.xli.3.529

The Daily Star; https://www-thedailystar-net.cdn.ampproject.org/v/s/www.thedailystar.net/editorial/extracurricular-activities-schools-1350106? amp_js_v=a6\&amp_gsa=1\&amp\&usqp=mq331AQHKAFQArABIA\%3D\%3D \#aoh=16134697098597\&referrer=https\%3A\%2F\%2Fwww.google.com\&amp_tf=From activities-schools-1350106

Us Census Bureau; https://www.census.gov/newsroom/press-releases/2014/cb14-

224.html\#: :text=DECEMBER\%2009\%2C\%202014-,Nearly\%206\%200ut\%20of\%2010\%20Children,Extracurricular\%20Activities\%2C\%20Census\%20Bureau\%20R 
Weihua Fan \& Cathy M. Williams (2010) The effects of parental involvement on students' academic self-efficacy, engagement and intrinsic motivation, Educational Psychology, 30:1, 53-74, DOI: 10.1080/01443410903353302 